\title{
BIOELECTRICITY GENERATION in ANNULUS STRUCTURE OF SINGLE CHAMBER MEMBRANE-LESS MICROBIAL FUEL CELL USING WASTEWATER FROM CHOCOLATE INDUSTRY
}

\author{
Ghasem Najafpour \\ Parisa Nouri \\ Mostafa Rahimnejad \\ Professor, Chemical Eng. Faculty, Babol Noshirvani \\ University of Technology, Babol, \\ Iran.
}

\begin{abstract}
Microbial Fuel Cell (MFC) is an efficient system for generating low power where wastewater is substrate for the biocatalyst. In this work, Annular Single Chamber Microbial Fuel Cell (ASCMFC) with spiral anode was fabricated and tested. Carbon cloth and stainless steel 400 meshes were selected as cathode and anode electrodes, respectively. In order to enhance the conductivity of anode, the graphite coating was applied. A $40 \%$ platinum as catalyst was used on carbon based cathode in MFC. The carbon cloth was coated with 5\% Nafion solution. In fact Nafion acts as Proton Exchange Membrane (PEM) in the fabricated MFC. For the first time, wastewater of Chocolate industry with COD $1400 \mathrm{mg} / \mathrm{L}$ was used as substrate in anode compartment. Also a mixture of anaerobic sludge from wastewater treatment plant (Qaem-Shahr, Iran) was introduced into MFC. Maximum voltage obtained in the ASCMFC system was $792 \mathrm{mV}$ in an open-circuit mode. Also, Fabricated MFC operating at $30{ }^{\circ} \mathrm{C}$, the maximum achieved power density using an external resistance of $500 \Omega$ was about $4.8 \mathrm{~W} / \mathrm{m} 3$. The upshots from single chamber MFC were compared to dual chamber MFC. The findings demonstrate that, due to the generated high power density and voltage by the cell, the ASCMFC has a great potential for COD removal and wastewater treatment.
\end{abstract}

\section{KEYWORDS}

ASCMFC, Power Density, Bio-electricity, Chocolate wastewater.

https://doi.org/10.15626/Eco-Tech.2014.006 


\section{Linnaeus ECO-TECH '14}

Kalmar, Sweden, November 24-26, 2014

\section{INTRODUCTION}

As fossil fuel sources are depleted, alternative source of energy for replacement is required. Replacement and use of renewable energy may ensure safe and eco-friendly environment while air pollution and emission of toxic volatile compounds are eliminated. Energy derived from organic waste not only convert waste to energy but the advanced technology may be an attractive sustainable technology for alternative energy source [1-3].

Microbial Fuel Cell (MFC) has been developed for production of energy from biodegradable biomass. MFC has gained a lot of attentions to produce low voltage of electrical energy from natural substrates such as carbohydrates [4]. In MFC organic wastes and chemical oxygen demand (COD) are oxidized; in fact biological treatment may occur while living cells are generating electron in anode chamber; then transferred through electrical resistance [5]. In oxidation and reduction via biological processes electrons and protons are generated $[6,7]$. transmission of proton trough proton exchange membrane (PEM) create an opportunity for electrons and protons to meet on cathode for generating stable product known as hydrogen; then oxidized to water molecule [8]. Anaerobic condition must be established in anode for reduction of organic molecule to donate electron while cathode has to be aerobic for oxidation hydrogen $[2,9,10]$.

Microorganism are able to utilize nutrients present in aquatic environment such as domestic wastewater [11], food industry wastes such as chocolate [12], dairy, sewage baker and confectionery products [13-15], marine sediments [16], animal waste [17], anaerobic sewage sludge [18], and literally any biodegradable organic compounds. The performance of MFC can be altered by several factors such as inoculum, digestion rate of substrate, electron transfer rate, type of proton exchanger, proton mass transfer through liquid, internal and external cell resistance, ionic strength of the solution, electrode types and spacing [10, 19, 20].

In order to increase the cell output power, structural optimization is considered as the important parameter which has the highest influence on the cell efficiency. Most MFCs are operated at neutral $\mathrm{pH}$ for desired bacterial growth conditions. Due to lower proton concentration, MFCs have lower internal resistance than chemical fuel cells that incorporate alkaline or acid electrolytes. The internal resistance may decrease by increasing the conductivity of the solution and decrease in electrode spacing without any changes on the $\mathrm{pH}$ of system [21].

Considering the fact that temperature has a direct effect on the bacteria kinetic, the performance of MFC can be altered by temperature fluctuations as well. Investigations of FCs are normally accomplished at temperatures around 30 to $37^{\circ} \mathrm{C}$. The desired temperature ranges are based on growth activities of organisms even in room temperature $15-30{ }^{\circ} \mathrm{C}$ for mesophyll or at high temperatures $50-60{ }^{\circ} \mathrm{C}$ for thermophiles or at temperatures less than $15^{\circ} \mathrm{C}$ which is suitable for psychrophilic growth.

Type, size and fabrication routes of electrodes can also affect the performance and output power of FCs. Most used electrodes are carbon based such as carbon felt [22], carbon cloth [23], carbon paper [24], graphite granule [25], graphite brush [26], granular activated carbon [27], graphite rod [28], graphite fiber, graphite foam, RVC [29, 30]. The cathode 


\section{Linnaeus ECO-TECH '14}

Kalmar, Sweden, November 24-26, 2014

performance plays a pivotal role in overall cell performance. Platinum as an effective catalyst is widely utilized in the cathode electrode to compensate for the poor kinetic of oxygen reduction and promote the output power. The main disadvantage of platinum is its higher cost compared to other catalysts. However, a $0.5 \mathrm{mg} / \mathrm{cm}^{2}$ loading of $\mathrm{Pt}$ is used in most commercially available cathode electrodes and their performance have been investigated [19, 20].

Confectionery industries are an important sector of the food industry in terms of effluent and wastewater management. The effluents of these units are complex organic compounds such as polysaccharides, proteins, fatty acids and lipids. Normally COD is very high; for instance, a study conducted by Ozturk et al [31] the COD of wastewater for a confectionery factory in Turkey was $19900 \mathrm{mg} / \mathrm{L}$. Consequently, the effluents of confectionery industries are highly prone to biodegradation and can serve as suitable substrate for MFCs.

The purpose of present work is to fabricate and test an especial design of MFC known as annular single-chamber microbial fuel cell (ASCMFC) using wastewater as source of energy. The unit may be used as pretreatment unit for waste water treatment. In order to reduce manufacturing costs of ASCMFC, special configuration of anode with spiral geometry was chosen. Also to enhance efficiency of the MFC, graphite -coated stainless steel was applied in anode compartment.

\section{MATERIALS AND METHODS}

\subsection{ASCMFC design and construction}

\subsubsection{Fabrication of MFC body}

To construct the cell, a transparent Plexiglas plate with thick of $3 \mathrm{~cm}$ was used to fabricate the MFC.
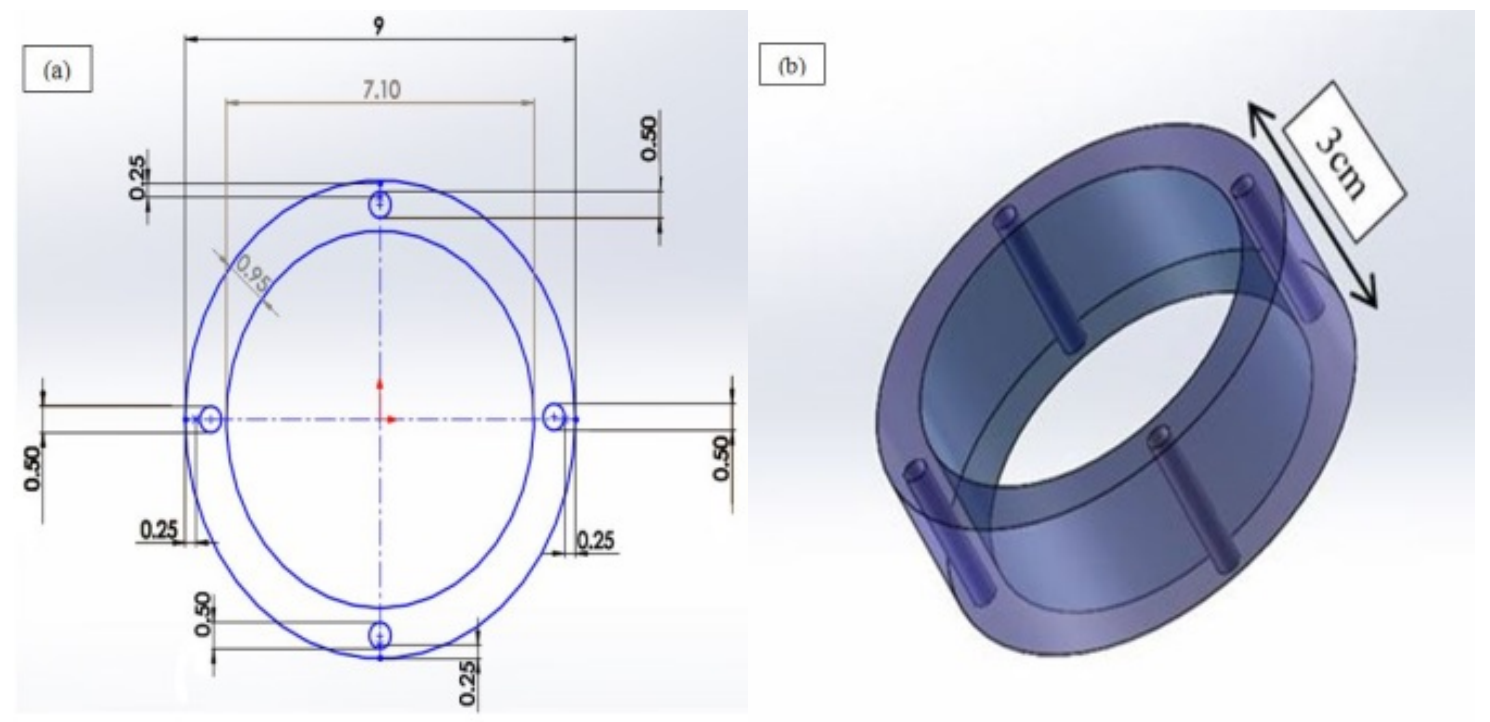

Figure 1. (a) 2D, (b) 3D scheme of SCMFC body 


\section{Linnaeus ECO-TECH '14}

Kalmar, Sweden, November 24-26, 2014

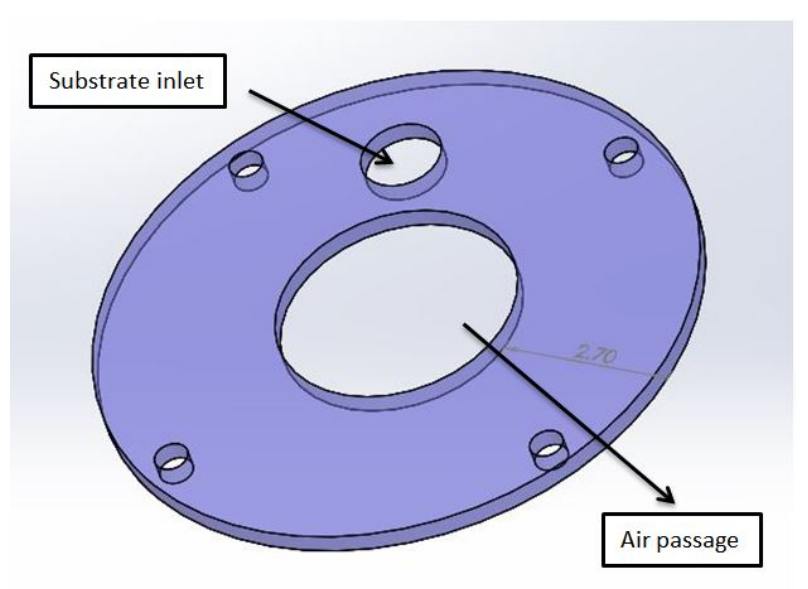

Figure 2. Top lid of ASCMFC

A circle with diameter of $9 \mathrm{~cm}$ was made on the surface of the specimen using Laser Cutter. The schematic diagram of MFC frame is shown in Figure 1. In order to serve as the main chamber of MFC, another hole with diameter of $7.1 \mathrm{~cm}$ was made on surface of the outer circle to have a chamber with inner and outer diameters of 7.1 and $9 \mathrm{~cm}$, respectively. Finally, 4 holes with diameter of $5 \mathrm{~mm}$ were placed on the edge of the chamber, offering spaces for screw placement (see Figure 1).

Top and bottom lid of the cell are the other parts of the body which were made out of a $3 \mathrm{~mm}$ thick transparent Plexiglas plate. In addition, 4 holes with diameter of $5 \mathrm{~mm}$ were located on the sides for screw insertion to connect lids to the chamber. It is important to note that the central hole was made to pass the air (see Figure 2).

\subsubsection{Design and construction of cathode holder}

A circle with outer diameter of $3.4 \mathrm{~cm}$ and inner diameter of $2.1 \mathrm{~cm}$ was made on the surface of a $3 \mathrm{~mm}$ thick Plexiglas plate. Four rectangular pillars with $3 \mathrm{~cm}$ height and $6 \mathrm{~mm}^{2}$ Cross section were cut from a $6 \mathrm{~mm}$ thick plate. Each of these pillars includes 3 holes to pass the wire. As shown in Figure 3, rectangular pillars were fixed between the circular plates (Figure 3).

In order to provide conductivity between the cathode electrode and the outer part of the cell, one meter-long cupper wire was used. As shown in Figure 4, the wire was wrapped around the cathode holder through the embedded holes. Finally, the cathode holder was encrusted with a black strip of improved cathode electrode. 


\section{Linnaeus ECO-TECH '14}

Kalmar, Sweden, November 24-26, 2014
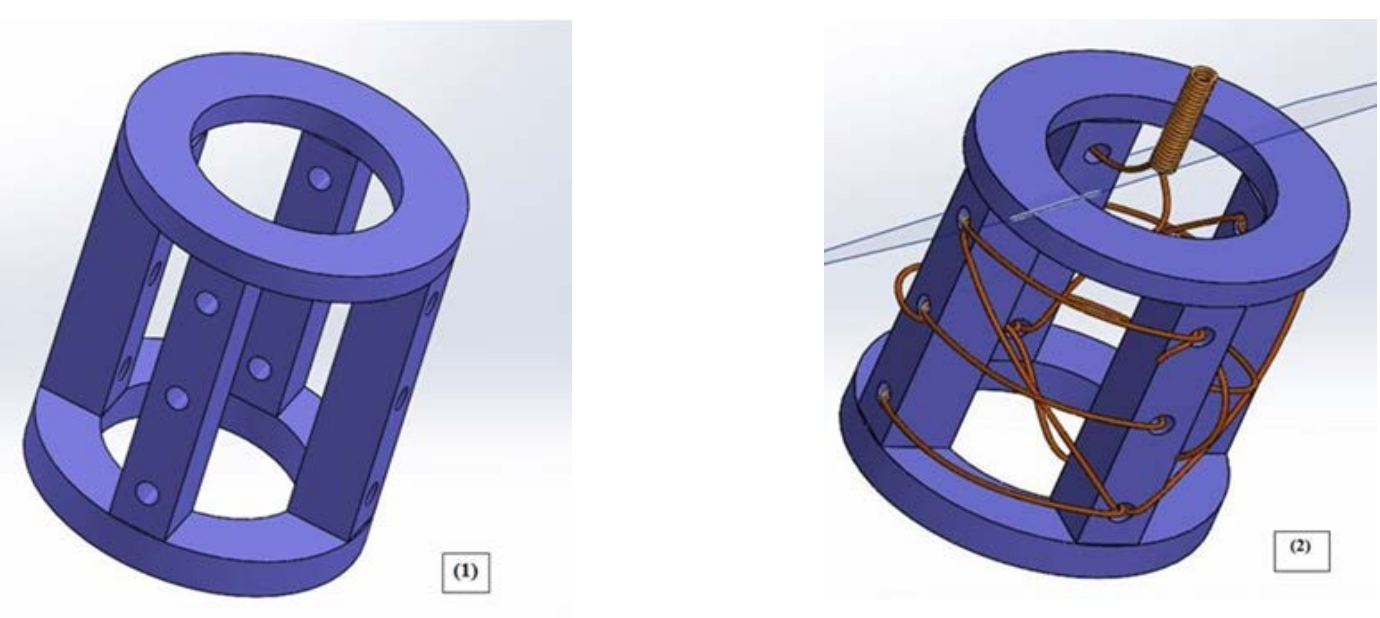

Figure 3. The central part of the ASCMFC, the cathode holder
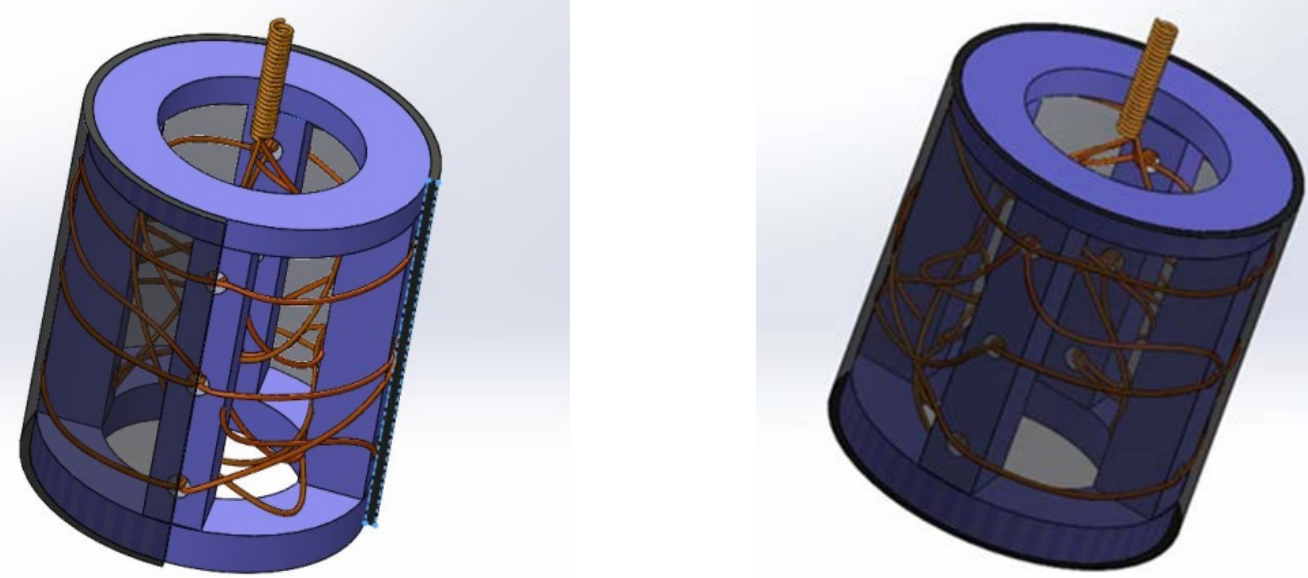

Figure 4. Holder covered by cathode electrode

\subsubsection{Anode electrode}

To fabricate anode electrode, a $2 \times 57 \mathrm{~cm}^{2}$ stainless steel mesh with 400 meshes was selected. Due to the high electrical resistance of stainless steel meshes, these meshes were coated with graphite to increase electrical conductivity. Use of steel mesh decreases operational costs dramatically compared with other types of electrodes. Furthermore, the mesh increases the possibility of growing the biological layer on its porous surface. On the other hand, flexibility and high ductility of steel along with its high mechanical resistance provides formability in a variety of geometries. In order to increase the surface area of anode and 


\section{Linnaeus ECO-TECH '14}

Kalmar, Sweden, November 24-26, 2014

simultaneously decrease the electrodes spacing and electrical resistance, spiral shaped mesh was used (see Figure 5).

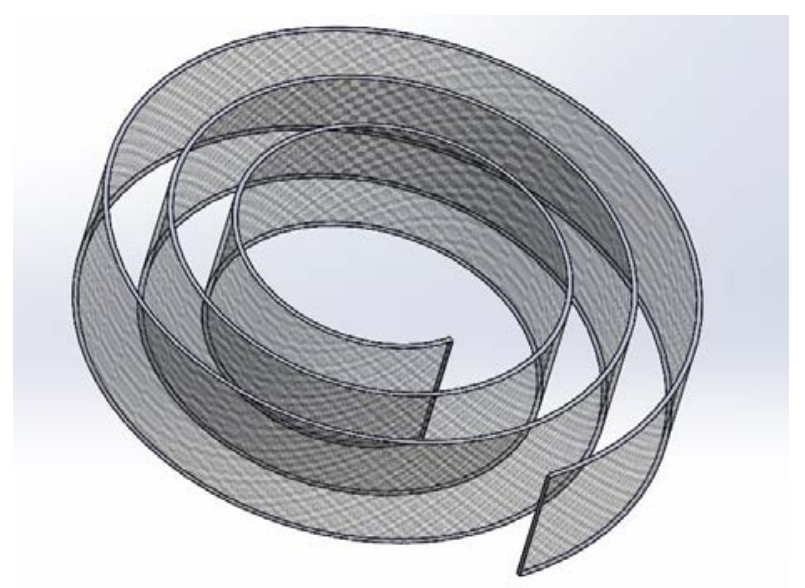

Figure 5.The metal strip used as anode

\subsubsection{Cathode electrode}

A $3.5 \times 11 \mathrm{~cm}$ of carbon cloth was selected to fabricate cathode electrode. By creating diffusion layers on the surface of cathode using the structure introduced by Cheng et al [20], one can enhance MFC's power generation. To describe the structure, first of all, carbon is placed as the first layer. The inner surface under the exposure of air was coated with polytetrafluoroethylene (PTFE) solution as second layer. The outer surface was coated with catalyst ink which is the third layer. The used carbon cloth in this study (E-TEC- USA) was coated with PTFE by factory default, so only catalyst was coated on the outer surface.

\subsubsection{Preparation of catalyst ink}

A mixture of $40 \%$ carbon powder-platinum (Alfa Aesar), 5\% nafion solution (Dupant), 99\% isopropanol (Merck) and distilled water were used to produce the catalyst ink by the method described elsewhere [20]. A $0.5 \mathrm{mg}$ of platinum for each $\mathrm{cm}^{2}$ of carbon cloth was required. After weighing these components, they were sonicated for 4 minutes until a homogeneous suspension was obtained. It should be noted here that if these components are not mixed well or the amount of water is not enough, mixing of carbon-platinum and nafion can lead to combustion of the mixture. If nafion or isopropanol exceeds the optimum value, obtained ink will be diluted and will cross the carbon cloth. On the other hand, if it is less than optimum value, catalyst particles agglomerate and the catalyst ink may not form very well. 


\section{Linnaeus ECO-TECH '14}

Kalmar, Sweden, November 24-26, 2014

\subsubsection{ASCMFC overall assembly}

In the studied system, the dimensions of cathode and anode electrodes were $3.5 \times 11 \mathrm{~cm}^{2}$ and $2 \times 57 \mathrm{~cm}^{2}$, respectively. The volume of anaerobic chamber was $90 \mathrm{~cm}^{3}$. The anode surface area can be increased by the aid of spiral geometry. Furthermore, the substrate passes shorter route in spiral geometry and can diffuse through the biological layer which was grown on the porous surface of anode [32] (See Figure 6).
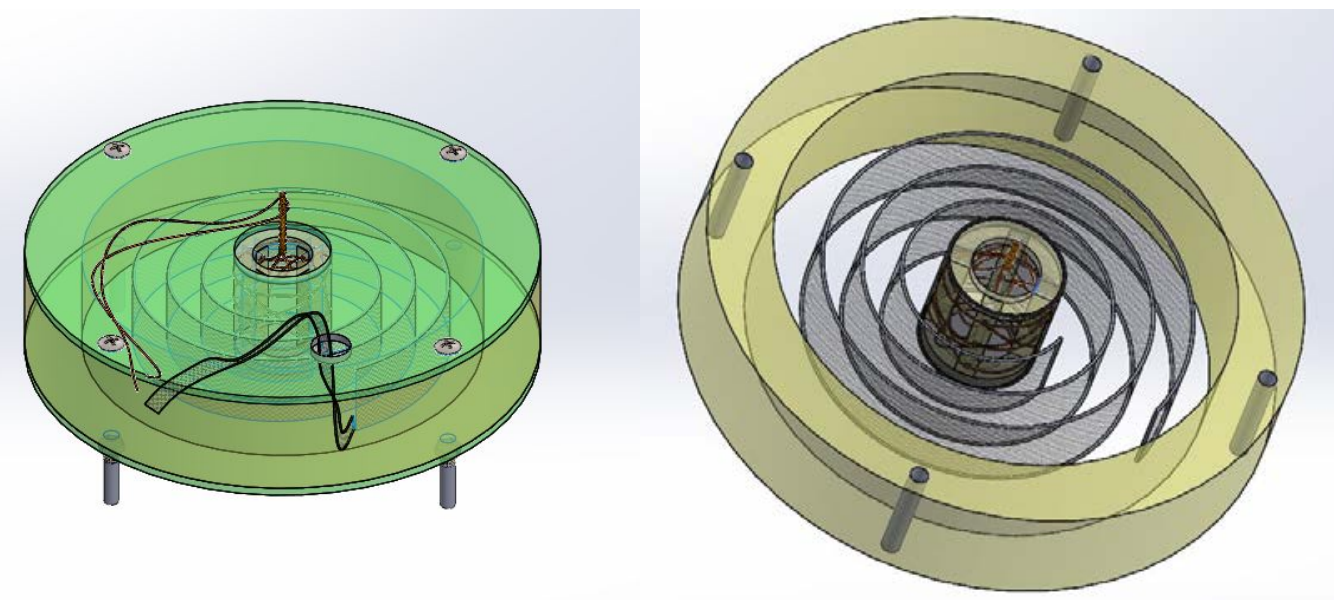

Figure 6. The scheme of the cell with circular structure and spiral anode

\subsection{Inoculation and performance of the cell}

In this study, wastewater of Farmand chocolate industry (Tehran, Iran) was used as substrate in the fuel cell. The oil phase of the wastewater was separated by physical treatment methods. The aqueous phase containing oily particulates and solid wastes were removed apart using coagulation processes. Consequently, the wastewater was majorly contaminated by hydrocarbons and water soluble fatty acids which were not separable by physical solutions but were strongly susceptible to biodegradation. Hence, biological processes were needed. Wastewater characterizations are given in Table 1.

Since mixed cultures cover a wide variety of microorganisms, they are very resistant to environmental fluctuations and are able to degrade wider ranges of substrates. In this study a mixture of anaerobic sludge from wastewater treatment plant in Qaem-Shahr was used as mixed culture. Organic and minerals materials are vital for bacteria nutrition and protoplasting purposes. Also, vitamin solutions are very useful for their growth and survival. Minerals and vitamins used in this work are given in Table 2.

Table 1. Wastewater Characterizations

\begin{tabular}{cl}
\hline Parameter & Values \\
\hline PH & 5.02 \\
COD & $1400 \mathrm{mg} / \mathrm{L}$ \\
Turbidity & $139.68 \mathrm{NTU}$ \\
Conductivity & $3160 \mu \mathrm{S} / \mathrm{cm}$ \\
TDS & $1.57 \mathrm{ppm}$ \\
Salt & $1.55 \mathrm{ppt}$ \\
\hline
\end{tabular}




\section{Linnaeus ECO-TECH '14}

Kalmar, Sweden, November 24-26, 2014

Table 2. Chemical composition of growth media added to MFCs [33]

\begin{tabular}{|llllll|}
\hline \multicolumn{2}{|c}{ Growth Media } & \multicolumn{2}{c|}{ Mineral Solution } & \multicolumn{2}{c|}{ Vitamin Solution } \\
\hline Compound & $\begin{array}{l}\text { Conc. } \\
(\mathrm{g} / \mathrm{L})\end{array}$ & Compound & $\begin{array}{l}\text { Conc. } \\
(\mathrm{g} / \mathrm{L})\end{array}$ & Compound & $\begin{array}{l}\text { Conc. } \\
(\mathrm{g} / \mathrm{L})\end{array}$ \\
\hline $\mathrm{KCl}$ & 0.13 & $\mathrm{CaCl}_{2} \cdot 2 \mathrm{H}_{2} \mathrm{O}$ & 0.132 & B-12 & 0.1 \\
\hline $\mathrm{Na}_{2} \mathrm{HPO}_{4}$ & 4.09 & $\mathrm{CoCl}_{2} \cdot 2 \mathrm{H}_{2} \mathrm{O}$ & 0.132 & Biotin & 1.96 \\
\hline $\mathrm{NaH}_{2} \mathrm{PO}_{4}$ & 2.544 & $\mathrm{CuSO}_{4} \cdot 5 \mathrm{H}_{2} \mathrm{O}$ & 0.0132 & Folic Acid & 2 \\
\hline $\mathrm{NH}_{4} \mathrm{Cl}$ & 0.31 & $\mathrm{FeSO}_{4} \cdot 7 \mathrm{H}_{2} \mathrm{O}$ & 0.132 & $\begin{array}{l}\text { Panthothenic } \\
\text { Acid }\end{array}$ & \\
\hline Mineral solution & $12.5 \mathrm{~mL}$ & $\mathrm{H}_{3} \mathrm{BO}_{3}$ & 0.0132 & Pyridoxine $\mathrm{HCl}$ & 3.6 \\
\hline Vitamin solution & $5 \quad \mathrm{~mL}$ & $\mathrm{~K}_{2} \mathrm{SO}_{4}$ & 3.96 & Riboflavine & 3.06 \\
\hline Distilled water & $1000 \mathrm{~mL}$ & $\mathrm{MnSO}_{4} \cdot \mathrm{H}_{2} \mathrm{O}$ & 0.66 & Thiamin & 3 \\
\hline \multicolumn{7}{r}{} & $\mathrm{NaCl}$ & 1.32 & & \\
\hline
\end{tabular}

As illustrated in Table 2, the growth media contains $12.5 \mathrm{ml}$ of mineral solution and $5 \mathrm{ml}$ of vitamin solution in addition to several types of mineral salts that were mixed and diluted to 1 liter. In order to adapt the anaerobic sludge with chocolate wastewater, $10 \mathrm{ml}$ of wastewater and $10 \mathrm{ml}$ of growth media were mixed and introduced into sludge every 2 days for 3 month. After these injections, $3 \mathrm{ml}$ of anaerobic sludge, $42 \mathrm{ml}$ of growth media and $45 \mathrm{ml}$ of wastewater were injected to the cell and the generated voltage was recorded. During the cell operation the $\mathrm{pH}$ of the media was dropped and sodium bicarbonate buffer solution, $\mathrm{pH} 10$, was used to prohibit the acidification of anolyte.

\subsection{Analytical technique}

The cell potential was measured and collected every 15 minutes using a data acquisition system. Electrical current measurements were performed in different resistances applied by a variable resistor. The generated voltages were recorded in each resistance and electrical currents and power were calculated by Eq1 and Eq2, respectively. In order to normalize the results, power and current were divided to anaerobic chamber's volume. The ultimate upshots were reported in terms of $\mathrm{W} / \mathrm{m}^{3}$ and $\mathrm{mA} / \mathrm{m}^{3}$ for power and current, respectively.

$\mathrm{I}=\mathrm{V} / \mathrm{R}$

(1)

$\mathrm{P}=\mathrm{V} \times \mathrm{I}$

(2)

\section{RESULTS AND DISCUSSION}

\subsection{Open-Circuit-Voltage (OCV)}

The open circuit test was the first test which performed on the ASCMFC along with the microbial enrichment process. 


\section{Linnaeus ECO-TECH '14}

Kalmar, Sweden, November 24-26, 2014

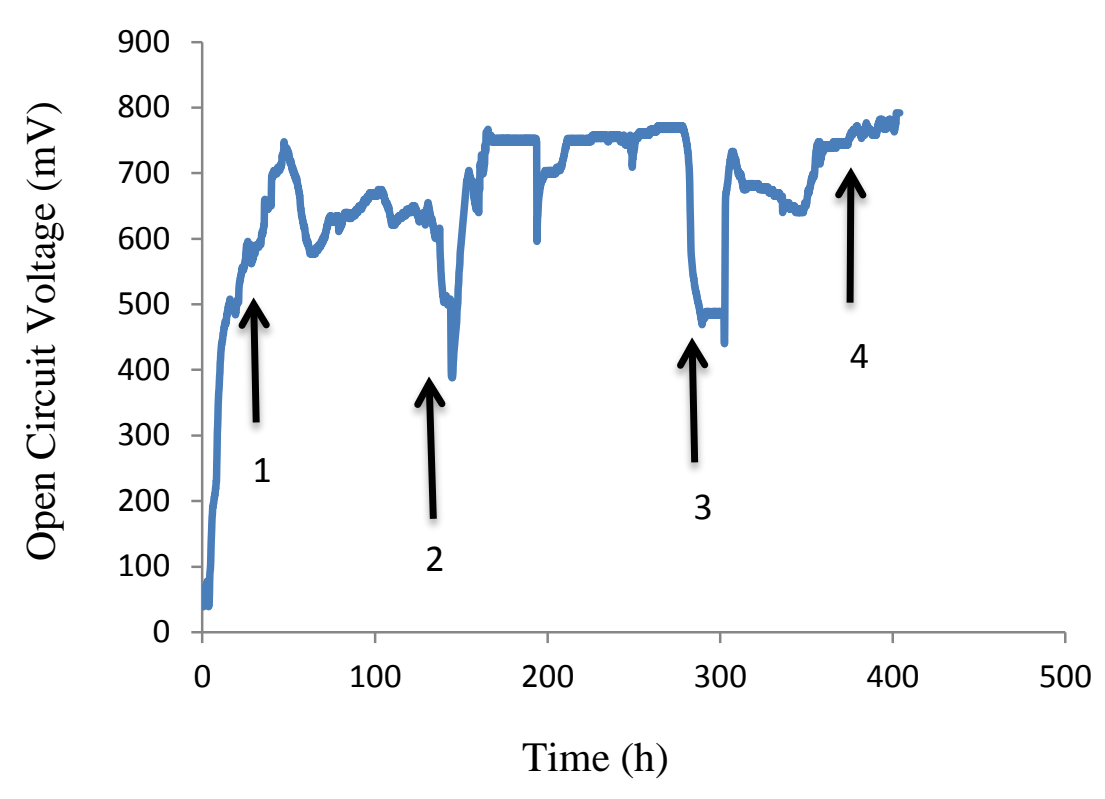

Figure 7.Measurement of ASCMFC opens circuit voltage. Addition of fresh substrate is indicated by arrows.

As illustrated in Figure 7, the open circuit voltage was examined for 403 hours. The initial voltage between anode and cathode was $68 \mathrm{mV}$, due to the chemical and biological differences. At the beginning of the process it showed a minor decline caused by incompatibilities between bacteria and the chamber conditions which named lag phase. Then, there is a substantial increase to $748 \mathrm{mV}$ after 46 hours. This upward trend was named logarithmic phase. For stationary phase, it was remained constant approximately around 750 $\mathrm{mV}$ with some fluctuations and gradual rise to the end of the test. It was perceived from the graph that, substrate consumption and decrease in $\mathrm{pH}$ leads to diminish voltage in stationary phase. But the decline in voltage was retrieved, by each injection of substrate and $\mathrm{pH}$ adjustment with phosphate buffer $(\mathrm{pH}=7)$. After the last injection (the injection number 4 shown in Figure 7) maximum voltage obtained $792 \mathrm{mV}$ and remained Table at this voltage without any noticeable differences. Finally it was found that, microbial enrichment was completed and further investigation was conducted.

\subsection{Effect of external resistance on the performance of ASCMFC}

With the application of external resistance, the system was switched to closed circuit mode and electrical currents were evaluated over time. External resistances of 500 and $300 \Omega$ were 


\section{Linnaeus ECO-TECH '14}

Kalmar, Sweden, November 24-26, 2014

applied and potential variations were recorded with each resistance for 382 and 264 hours, respectively. During the test, fresh wastewater was injected to the cell 4 times. As illustrated in Figure 8 using resistance of $500 \Omega$, the maximum observed values for generated current and power density were $0.932 \mathrm{~mA}$ and $4.82 \mathrm{~W} / \mathrm{m} 3$, respectively. Likewise, using resistance of $300 \Omega$ the maximum obtained values for generated current and power density were $1.253 \mathrm{~mA}$ and $5.23 \mathrm{~W} / \mathrm{m} 3$, respectively. Similar for OCV test, wastewater renewal at each decline causes abrupt ascends during the test.
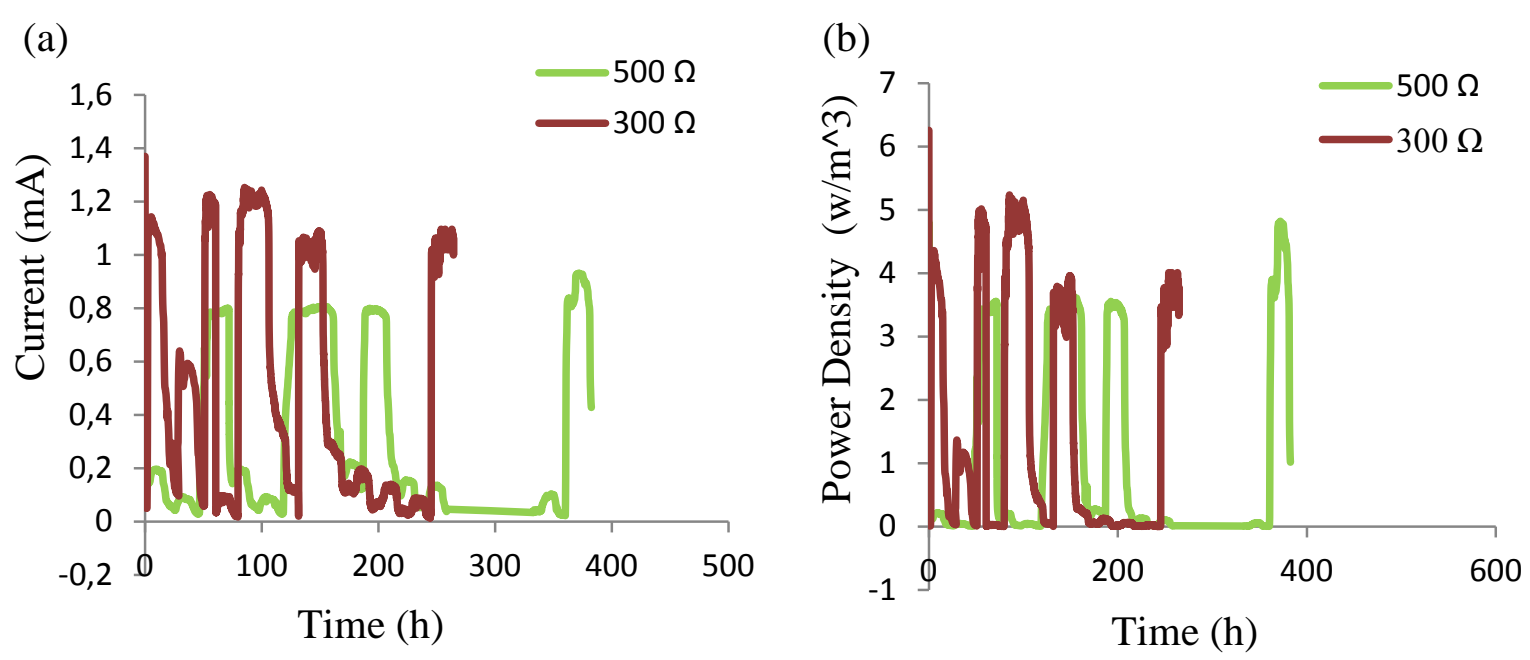

Figure 8. (a) Current and (b) Power density variations

These ascends were attributed to wastewater renewal and subsequently generation of electrons by oxidation/reduction processes. Investigations of system response to wastewater renewal at $300 \Omega$ resistance showed that, the period of ascending phase was shorter, the stationary phase lased shorter and the period of decline phase was longer compared to $500 \Omega$ resistance. Moreover the system response to wastewater renewal was faster at lower resistance. With the application of lower electrical resistance, more electrons were transferred toward the cathode and consumed in the proximity of oxygen. Since the substrate oxidation reaction is an equilibrium reaction, high consumption of generated electrons caused high amounts of substrate to be oxidized. Thus, high oxidation rates are expected at low electrical resistances. At lower resistances, the electron transfer rate was higher compared to the generation rate. As a consequence, the period of ascending phase was shorter and the stationary phase lasted longer.

\subsection{COD removal}

One of the most important methods to measure the high organic loading of wastewater is the COD test. It is defined as the amount of oxygen required to convert organic compounds to water and carbon dioxide. The value of measured COD is proportional to the level of organic contaminants. That is, the higher value for COD is an indication of high levels of available organic compounds. Figure 9 illustrates COD removal for ASCMFC. The COD of used 
wastewater was $1400 \mathrm{mg} / \mathrm{L}$ which reduced to123.2 mg/L after 96 hours and COD removal was $91.2 \%$.

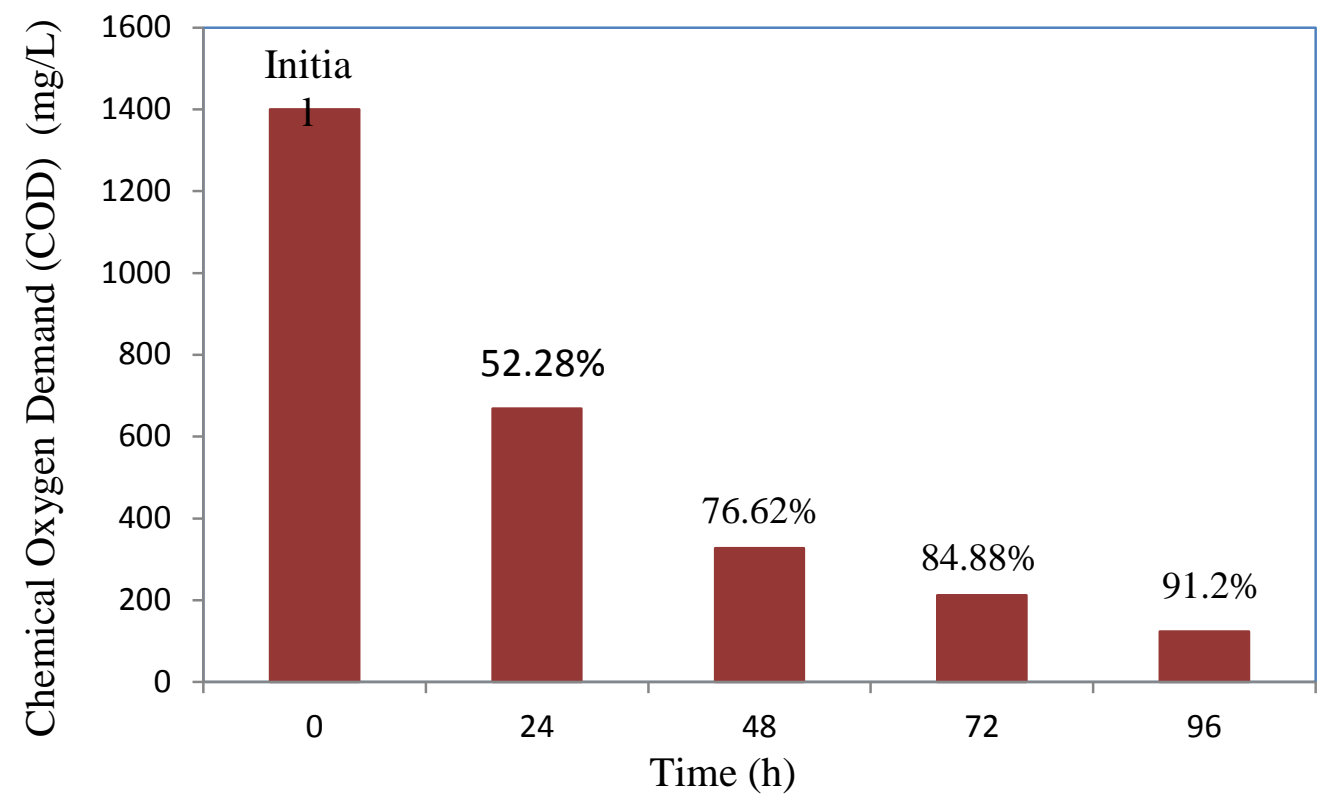

Figure 9. COD removal

\section{CONCLUSIONS}

In this work, an ASCMFC was fabricated for wastewater treatment and power generation. Chocolate wastewater was used as the substrate in the fabricated fuel cell. Different electrical resistances were applied to the system and the MFC responses were assessed. Investigations on electrical current using resistances of 300 and $500 \Omega$ revealed that at low resistance, the system response was fast and the time period of ascending phase was short. Maximum reported value for OCV was $792 \mathrm{mV}$. The MFC was also highly capable of COD removal which reduced the COD value by more than $91 \%$. This remarkable efficiency in COD removal envisages the use of this MFC for wastewater treatment in shorter short period of time.

\section{ACKNOWLEDGMENTS}

The authors wish to acknowledge Biotechnology Research Center, Noshirvani University of Technology, Babol, Iran for the facilities provided to accomplish present work.

\section{REFRENCE}

[1]. Pham, T., K. Rabaey, P. Aelterman, P. Clauwaert, L. De Schamphelaire, N. Boon, and W. Verstraete, 2006,Microbial fuel cells in relation to conventional anaerobic digestion technology. Engineering in Life Sciences, 6(3), 285-292. 


\section{Linnaeus ECO-TECH '14}

Kalmar, Sweden, November 24-26, 2014

[2]. Ghasemi, M., W.R.W. Daud, S.H. Hassan, S.-E. Oh, M. Ismail, M. Rahimnejad, and J.M. Jahim, 2013,Nano-structured carbon as electrode material in microbial fuel cells: a comprehensive review. Journal of Alloys and Compounds, 580, 245-255.

[3]. Tardast, A., M. Rahimnejad, G. Najafpour, A. Ghoreyshi, G.C. Premier, G. Bakeri, and S.-E. Oh, 2014,Use of artificial neural network for the prediction of bioelectricity production in a membrane less microbial fuel cell. Fuel, 117, 697-703.

[4]. Rabaey, K., G. Lissens, S.D. Siciliano, and W. Verstraete, 2003,A microbial fuel cell capable of converting glucose to electricity at high rate and efficiency. Biotechnology letters, 25(18), 1531-1535.

[5]. Rahimnejad, M., N. Mokhtarian, G. Najafpour, W. Daud, and A. Ghoreyshi, 2009,Low voltage power generation in abiofuel cell using anaerobic cultures. World Appl Sci J, 6, $1585-1588$.

[6]. Liu, H., R. Ramnarayanan, and B.E. Logan, 2004,Production of electricity during wastewater treatment using a single chamber microbial fuel cell. Environmental science \& technology, 38(7), 2281-2285.

[7]. Cheng, S., W. Liu, J. Guo, D. Sun, B. Pan, Y. Ye, W. Ding, H. Huang, and F. Li, 2014,Effects of hydraulic pressure on the performance of single chamber air-cathode microbial fuel cells. Biosensors and Bioelectronics, 56, 264-270.

[8]. Liu, B. and B. Li, 2014,Single chamber microbial fuel cells (SCMFCs) treating wastewater containing methanol. International Journal of Hydrogen Energy, 39(5), 2340-2344.

[9]. Logan, B.E. and J.M. Regan, 2006,Microbial fuel cells-challenges and applications. Environmental science \& technology, 40(17), 5172-5180.

[10]. Rahimnejad, M., A.A. Ghoreyshi, G. Najafpour, and T. Jafary, 2011,Power generation from organic substrate in batch and continuous flow microbial fuel cell operations. Applied Energy, 88(11), 3999-4004.

[11]. Ahn, Y. and B.E. Logan, 2010,Effectiveness of domestic wastewater treatment using microbial fuel cells at ambient and mesophilic temperatures. Bioresource technology, 101(2), 469-475.

[12]. Patil, S.A., V.P. Surakasi, S. Koul, S. Ijmulwar, A. Vivek, Y. Shouche, and B. Kapadnis, 2009,Electricity generation using chocolate industry wastewater and its treatment in activated sludge based microbial fuel cell and analysis of developed microbial community in the anode chamber. Bioresource technology, 100(21), 51325139.

[13]. Kiely, P.D., R. Cusick, D.F. Call, P.A. Selembo, J.M. Regan, and B.E. Logan, 2011,Anode microbial communities produced by changing from microbial fuel cell to microbial electrolysis cell operation using two different wastewaters. Bioresource technology, 102(1), 388-394.

[14]. Velasquez-Orta, S., I. Head, T. Curtis, and K. Scott, 2011,Factors affecting current production in microbial fuel cells using different industrial wastewaters. Bioresource technology, 102(8), 5105-5112.

[15]. Nimje, V.R., C.-Y. Chen, H.-R. Chen, C.-C. Chen, Y.M. Huang, M.-J. Tseng, K.-C. Cheng, and Y.-F. Chang, 2012,Comparative bioelectricity production from various wastewaters in microbial fuel cells using mixed cultures and a pure strain of $<i>$ Shewanella oneidensis $</ i>$. Bioresource technology, 104, 315-323.

[16]. Tender, L.M., C.E. Reimers, H.A. Stecher, D.E. Holmes, D.R. Bond, D.A. Lowy, K. Pilobello, S.J. Fertig, and D.R. Lovley, 2002,Harnessing microbially generated power on the seafloor. nature biotechnology, 20(8), 821-825. 


\section{Linnaeus ECO-TECH '14}

Kalmar, Sweden, November 24-26, 2014

[17]. Min, B., J. Kim, S. Oh, J.M. Regan, and B.E. Logan, 2005,Electricity generation from swine wastewater using microbial fuel cells. Water research, 39(20), 4961-4968.

[18]. Kim, J.R., B. Min, and B.E. Logan, 2005,Evaluation of procedures to acclimate a microbial fuel cell for electricity production. Applied microbiology and biotechnology, 68(1), 23-30.

[19]. Cheng, S., H. Liu, and B.E. Logan, 2006,Power densities using different cathode catalysts (Pt and CoTMPP) and polymer binders (Nafion and PTFE) in single chamber microbial fuel cells. Environmental science \& technology, 40(1), 364-369.

[20]. Cheng, S., H. Liu, and B.E. Logan, 2006,Increased performance of single-chamber microbial fuel cells using an improved cathode structure. Electrochemistry Communications, 8(3), 489-494.

[21]. Liu, H., S. Cheng, and B.E. Logan, 2005,Power generation in fed-batch microbial fuel cells as a function of ionic strength, temperature, and reactor configuration. Environmental science \& technology, 39(14), 5488-5493.

[22]. Martin, E., O. Savadogo, S. Guiot, and B. Tartakovsky, 2010,The influence of operational conditions on the performance of a microbial fuel cell seeded with mesophilic anaerobic sludge. Biochemical engineering journal, 51(3), 132-139.

[23]. Zhuang, L., C. Feng, S. Zhou, Y. Li, and Y. Wang, 2010,Comparison of membraneand cloth-cathode assembly for scalable microbial fuel cells: construction, performance and cost. Process Biochemistry, 45(6), 929-934.

[24]. Yuan, Y. and S. Kim, 2008,Improved performance of a microbial fuel cell with polypyrrole/carbon black composite coated carbon paper anodes. Bulletin of the Korean Chemical Society, 29(7), 1344-1348.

[25]. Feng, Y., H. Lee, X. Wang, Y. Liu, and W. He, 2010,Continuous electricity generation by a graphite granule baffled air-cathode microbial fuel cell. Bioresource technology, 101(2), 632-638.

[26]. Logan, B., S. Cheng, V. Watson, and G. Estadt, 2007,Graphite fiber brush anodes for increased power production in air-cathode microbial fuel cells. Environmental science \& technology, 41(9), 3341-3346.

[27]. Jiang, D. and B. Li, 2009,Granular activated carbon single-chamber microbial fuel cells (GAC-SCMFCs): a design suitable for large-scale wastewater treatment processes. Biochemical Engineering Journal, 47(1), 31-37.

[28]. Chaudhuri, S.K. and D.R. Lovley, 2003,Electricity generation by direct oxidation of glucose in mediatorless microbial fuel cells. Nature biotechnology, 21(10), 12291232.

[29]. He, Z., S.D. Minteer, and L.T. Angenent, 2005,Electricity generation from artificial wastewater using an upflow microbial fuel cell. Environmental science \& technology, 39(14), 5262-5267.

[30]. Zhou, M., M. Chi, J. Luo, H. He, and T. Jin, 2011,An overview of electrode materials in microbial fuel cells. Journal of Power Sources, 196(10), 4427-4435.

[31]. Mustafa Evren Ersahin , H.O., Recep Kaan Dereli, Izzet Ozturk, Anaerobic Treatment of Industrial Effluents: An Overview of Applications2011.

[32]. Mahdi Mardanpour, M., M. Nasr Esfahany, T. Behzad, and R. Sedaqatvand, 2012,Single chamber microbial fuel cell with spiral anode for dairy wastewater treatment. Biosensors and Bioelectronics, 38(1), 264-269.

[33]. Morris, J.M. and S. Jin, 2008,Feasibility of using microbial fuel cell technology for bioremediation of hydrocarbons in groundwater. Journal of environmental science and health. Part A, Toxic/hazardous substances \& environmental engineering, 43(1), 1823. 